\title{
Polysaccharide isolated from Agardhiella ramosissima: Chemical structure and anti-inflammation activity
}

\author{
Jalles A. Batista ${ }^{a}$, Eulina G.N. Dias ${ }^{a}$, Tarcisio V. Brito ${ }^{a}$, Rafael S. Prudêncio ${ }^{a}$, \\ Renan O. Silva ${ }^{a}$, Ronaldo A. Ribeiro ${ }^{\mathrm{b}}$, Marcellus Henrique L.P. Souza ${ }^{\mathrm{b}}$, \\ Regina C.M. de Paula ${ }^{\mathrm{d}}$, Judith P.A. Feitosa ${ }^{\mathrm{d}}$, Luciano S. Chaves ${ }^{\mathrm{c}}$, Márcia R.S. Melo ${ }^{\mathrm{c}}$, \\ Ana L.P. Freitas ${ }^{c}$, Jand-Venes R. Medeiros ${ }^{a}$, André L.R. Barbosa ${ }^{a, *}$ \\ ${ }^{a}$ LAFFEX - Laboratory of Experimental Physiopharmacology, Biotechnology and Biodiversity Center Research (BIOTEC), Federal University of Piauí-CMRV, \\ Parnaiba, Piauí, Brazil \\ ${ }^{\mathrm{b}}$ LAFICA - Laboratory of Pharmacology of Inflammation and Cancer, Department of Physiology and Pharmacology, Federal University of Ceará, Fortaleza, \\ CE, Brazil \\ ${ }^{\mathrm{c}}$ Laboratory of Proteins and Carbohydrates of Marine Algae, Department of Biochemistry and Molecular Biology, Federal University of Ceará, Fortaleza, \\ Brazil \\ d Polymer Laboratory, Department of Organic and Inorganic Chemistry, Federal University of Ceará, Fortaleza, Brazil
}

\section{A R T I C L E I N F O}

\section{Article history:}

Received 8 June 2013

Received in revised form 20 August 2013

Accepted 23 August 2013

Available online 28 August 2013

\section{Keywords:}

Agardhiella ramosissima

Polysaccharide

Chemical structure

Anti-inflammatory effect

Antinociceptive action

\begin{abstract}
A B S T R A C T
The sulfated polysaccharide (PLS) fraction of Agardhiella ramosissima was characterized by microanalysis, infrared spectroscopy, NMR and gas-liquid-chromatography-mass-spectrometry. The main constituent of PLS was the $\iota$ carrageenan. The monosaccharide composition of the PLS showed galactose, 3,6anhydrogalactose and 6-O-methylgalactose. The PLS (30 $\left.\mathrm{mg} \mathrm{kg}^{-1}\right)$ significantly reduced the paw oedema induced by carrageenan, dextran, histamine and serotonin and also was able to significantly inhibit leucocyte migration into the peritoneal cavity and decrease the concentration of myeloperoxidase (MPO) in paw tissue. In the antinociceptive tests, the pre-treatment with PLS reduced the number of writhes, the licking time but did not increase the latency time of response. This study demonstrates for the first time the anti-inflammatory and anti-nociceptive effects of PLS from A. ramosissima. Thus, we concluded that PLS could be a new natural tool in pain and acute inflammatory conditions.
\end{abstract}

(c) 2013 Elsevier Ltd. All rights reserved.

\section{Introduction}

The search for compounds with pharmacological properties from natural products has led to the discovery of pharmacologically active substances with important applications both in the experimental field and identification of active principles with therapeutic interest (Barbosa-Filho et al., 2008; Corrêa, Melo, \& Costa, 2008; Konig \& Wright, 1995; Rocha, Fernandes, Quintão, Campos, \& Calixto, 2006; Sousa et al., 2008).

Marine organisms are sources of numerous compounds with pharmacological properties (Arif, Al-Hazzani, Kunhi, \& Al-Khodairy, 2004). The variety and complexity of these molecules which are the secondary metabolites of algae is difficult to be obtained by chemical synthesis and are reaching highly refined forms for protection against the weather, pollution and predators (Viegas, Bolzani, \& Barreiro, 2006).

\footnotetext{
* Corresponding author. Tel.: +55 8699567821.

E-mail address: andreluiz@ufpi.edu.br (A.L.R. Barbosa).
}

Seaweeds are found on coasts throughout the world. Many species of marine macroalgae are used as food sources and are rich in sulphated polysaccharides (Kusaykin et al., 2008; Wijesekara, Pangestuti, \& Kim, 2011). Some of these polysaccharides, known as agars or carrageenan, have valuable gelling and stabilizing properties. These polysaccharides are industrially prepared from algae on a large scale as phycocolloids for many practical purposes (Selby et al., 1993; Therkelsen, 1993).

Recently, there has been an increasing interest in systematic screening of the biological activity of PLSs isolated from marine algae. Some of these polysaccharides have been developed into new drugs (Kaji et al., 2004; Zhou et al., 2004). In general, the biological activity of a polysaccharide from marine algae is related to its molecular size and anticoagulant properties (Cumashi et al., 2007), as well as gastroprotective, anti-nociceptive (Silva et al., 2011) and anti-inflammatory activities (Rocha et al., 2006), which make it relevant for pharmaceutical applications.

Agardhiella ramosissima is a red seaweed belonging to the Solieriaceae family (Gigartinales, Rhodophyta). Species of the order Gigartinales produce a carrageenan-like PLS, which is a polymer 
comprising alternating $(1 \rightarrow 3)$-linked $\beta$-D-galactopyranose units, as well as $(1 \rightarrow 4)$-linked $\alpha$-D-galactopyranose units that are frequently in the 3,6-anhydro form (Pereira \& Mesquita, 2003; Usov, 2011).

The inflammatory process is a temporal phenomenon, characterized by intense neutrophil infiltration and a variety of mediators such as histamines, serotonin, bradykinins, nitric oxide, and prostaglandins (Carvalho et al., 1996; Hajare et al., 2001; Srinivasan et al., 2001). There is a strong association between the inflammatory process and the development of pain. Inflammatory pain is accompanied by increased excitability of the peripheral nociceptive sensory fibres produced by the actions of inflammatory mediators (Linley, Rose, Ooi, \& Gamper, 2010).

The aim of the present study was to clarify the chemical characterization of PLS fraction from the red marine alga $A$. ramosissima and investigate its unexplored anti-nociceptive and anti-inflammatory activities by using experimental models of nociception and inflammation.

\section{Experimental}

\subsection{Drugs and reagents}

The following drugs and reagents were used: carrageenan (Sigma-Aldrich), dextran sulphate (Sigma-Aldrich), indomethacin (Sigma-Aldrich), bradykinin (Sigma-Aldrich), histamine (Sigma-Aldrich), hexadecyltrimethylammonium bromide (HTAB), acetic acid, formalin, and morphine sulphate. All drugs were dissolved in sterile saline $(0.9 \% \mathrm{NaCl})$.

\subsection{Animals}

Male Swiss mice weighing 25-30 g were used. The animals were housed in temperature-controlled rooms and received food and water ad libitum. All experiments were conducted in accordance with the currently established principles for the care and use of research animals (National Institutes of Health $[\mathrm{NIH}]$ guidelines) and were approved under no. 020/12 in 2012 by the Ethics Committee of the Federal University of Piauí, Brazil.

\subsection{Extraction and fractioning of PLS of A. ramosissima}

The red seaweed $A$. ramosissima was harvested at Flexeiras beach, Trairí, Ceará, and a voucher was deposited in the Prisco Bezerra Herbarium at the Federal University of Ceará (Number 34.738). The samples were cleaned of epiphytes, washed with distilled water, and stored at $-20^{\circ} \mathrm{C}$. The dried tissue $(5 \mathrm{~g})$ was milled and suspended in $250 \mathrm{~mL}$ of $0.1 \mathrm{M}$ sodium acetate buffer ( $\mathrm{pH} 6.0$ ) containing $510 \mathrm{mg}$ of papain (E. Merck), $5 \mathrm{mM}$ EDTA, $5 \mathrm{mM}$ cysteine and incubated at $60^{\circ} \mathrm{C}$ for $12 \mathrm{~h}$. The residue was removed by filtration and centrifuged at $2700 \times g$ for $25 \mathrm{~min}$ at $4{ }^{\circ} \mathrm{C}$. The PLSs were precipitated by the addition of $48 \mathrm{~mL}$ of $10 \%$ cetylpyridinium chloride (CPC, Sigma Chemical). The mixture was centrifuged at $2700 \times \mathrm{g}$ for $25 \mathrm{~min}$ at $4{ }^{\circ} \mathrm{C}$. The polysaccharides in the pellet were washed with $200 \mathrm{~mL}$ of $0.05 \%$ cetylpyridinium chloride solution, dissolved in $174 \mathrm{~mL}$ of a $2 \mathrm{M} \mathrm{NaCl} /$ ethanol $(100: 15, \mathrm{v} / \mathrm{v})$ solution, and then precipitated with $200 \mathrm{~mL}$ of $70 \%$ ethanol (v/v), for $12 \mathrm{~h}$ at $4{ }^{\circ} \mathrm{C}$. After further centrifugation $\left(2700 \times \mathrm{g} 4{ }^{\circ} \mathrm{C} ; 25 \mathrm{~min}\right)$, the precipitate was washed twice with $200 \mathrm{~mL}$ of absolute ethanol and dried with acetone under hot air flow $\left(60^{\circ} \mathrm{C}\right)$.

\subsection{Chemical analysis}

Total neutral carbohydrate content of fractions was determined by the phenol-sulphuric acid method (Dubois, Gilles, Hamilton, Rebers, \& Smith, 1956) using D-galactose to construct the standard curve. The content of soluble proteins was measured by the method of Bradford (Bradford, 1976), using bovine serum albumin (BSA) as standard. The amount of sulfate group was estimated by the Dodgson and Price's method (Dodgson \& Price, 1962) using sodium sulfate $\left(\mathrm{Na}_{2} \mathrm{SO}_{4}\right)$ as standard. Moisture and ash was calculated by heating at $105^{\circ} \mathrm{C}$ and $750{ }^{\circ} \mathrm{C}$ respectively a desire amount of sample until constant weight.

\subsection{Monosaccharide composition}

The monosaccharide composition was estimated by gas-liquidchromatography-mass-spectrometry (GC-MS) of derived alditols using reductive hydrolysis procedure (Stevenson \& Furneaux, 1991). A Varian 3300 chromatograph and a Finnigan Mat ITD spectrometer were utilized. BD 225 column $(30 \mathrm{~m} \times 0.25 \mathrm{~mm})$ was used. Helium was the carrier gas $(1 \mathrm{~mL} / \mathrm{min})$.

\subsection{Infrared spectroscopy}

Fourier transform infrared (FT-IR) spectra of $\mathrm{KBr}$ pellets of the polysaccharides were recorded in a Shimadzu IR spectrophotomer (model 8300) scanning between 400 and $4000 \mathrm{~cm}^{-1}$.

\subsection{Nuclear magnetic resonance spectroscopy}

${ }^{13} \mathrm{C}$ spectra of $2.5 \%(\mathrm{w} / \mathrm{v})$ solutions in $\mathrm{D}_{2} \mathrm{O}$ were recorded at $353 \mathrm{~K}$ on a Fourier transform Bruker Avance DRX 500 spectrometer with an inverse multinuclear gradient probe-head equipped with z-shielded gradient coils, and with Silicon Graphics. Acetone was used as the internal standard (31.07 ppm for $\left.{ }^{13} \mathrm{C}\right)$.

\subsection{Carrageenan type $\lambda$-induced paw oedema}

The animals were randomly divided into 6 groups $(n=5)$, and oedema was induced by the injection into the right hind paw of $50 \mu \mathrm{L}$ of a suspension of carrageenan $(500 \mu \mathrm{g} / \mathrm{paw})$ in $0.9 \%$ sterile saline (group I). Mice were pretreated intraperitoneally (i.p.) with either $0.9 \% \mathrm{NaCl}$ (group II untreated control); $10 \mathrm{mg} \mathrm{kg}^{-1}$ indomethacin (group III reference control); or PLS 3, 10 or $30 \mathrm{mg} \mathrm{kg}^{-1}$ (groups IV, V, and VI, respectively). Paw volume was measured immediately before (Vo), and at 1,2,3, and $4 \mathrm{~h}$ after carrageenan treatment (Vt) as previously described by Winter, Risley, and Nuss (1962) with a plethysmometer (Panlab, Barcelona, Spain). The effect of pretreatment was calculated as the percentage of inhibition of oedema relative to the paw volume of the saline-treated controls by using the following formula (Lanhers et al., 1991):

$\%$ inibition of edema $=\frac{\left(v_{t}-v_{o}\right) \text { control }-\left(v_{t}-v_{o}\right) \text { treated }}{\left(v_{t}-v_{o}\right) \text { control }} \times 100$

\subsection{Effect of PLS on paw oedema induced by different} inflammatory agents

To induce paw oedema with different inflammatory agents, the animals were administered $50 \mu \mathrm{L}$ injections of dextran $(500 \mu \mathrm{g} /$ paw $)$, serotonin $(1 \%, w / v)$, or histamine $(1 \%, w / v)$ into the right hind paw (Vasconcelos et al., 2011). One group received $50 \mu \mathrm{L}$ of $0.9 \%$ sterile saline and served as an untreated control. PLS (30 $\left.\mathrm{mg} \mathrm{kg}^{-1}\right)$ or indomethacin $\left(10 \mathrm{mg} \mathrm{kg}^{-1}\right.$, reference control) was injected i.p. 30 min before these intraplantar injections of phlogistic agents.

\subsection{Determination of myeloperoxidase activity}

The extent of neutrophil accumulation in the mouse paw was measured by a myeloperoxidase (MPO) activity evaluation. Briefly, 
50-100 mg hind paw tissue was homogenized in $1 \mathrm{~mL}$ potassium buffer with $0.5 \%$ hexadecyltrimethylammonium bromide for each $50 \mathrm{mg}$ of tissue. The homogenate was centrifuged at $40,000 \times \mathrm{g}$ for $7 \mathrm{~min}$ at $4{ }^{\circ} \mathrm{C}$. MPO activity in the resuspended pellet was assayed by measuring the change in absorbance at $450 \mathrm{~nm}$ using odianisidinedihydrochloride and $1 \%$ hydrogen peroxide. The results were reported as MPO units/mg tissue. A unit of MPO (UMPO) activity was defined as that converting $1 \mathrm{mmol}$ hydrogen peroxide to water in $1 \mathrm{~min}$ at $22^{\circ} \mathrm{C}$ (Bradley, Christensen, \& Rothstein, 1982).

\subsection{Peritonitis model in mice}

Mice were injected p.o. with $250 \mu \mathrm{L}$ sterile saline or indomethacin $10 \mathrm{mg} \mathrm{kg}^{-1}$ or PLS $30 \mathrm{mg} \mathrm{kg}^{-1}$. One hour later, the animals were injected i.p. with $250 \mu \mathrm{L}$ carrageenan ( $500 \mu \mathrm{g} /$ cavity) into the peritoneal cavity. Mice were euthanized $4 \mathrm{~h}$ later and the peritoneal cavity was washed with $1.5 \mathrm{~mL}$ of heparinized phosphate buffered saline (PBS) to harvest peritoneal cells. Total cell counts were performed in a Neubauer chamber, and differential cell counts (100 cells total) were carried out on cytocentrifuge slides stained with haematoxylin and eosin. The results are presented as the number of neutrophils per $\mathrm{mL}$ of peritoneal exudate.

\subsection{Acetic acid-induced writhing test}

The acetic-acid writhing test was used to evaluate analgesic activity (Collier, Dinneen, Johnson, \& Schneider, 1968). The mice ( $n=5$ per group) were injected (i.p.) with $0.6 \%$ acetic acid (10 $\mathrm{mL} \mathrm{kg}^{-1}$ body weight), and the intensity of nociception was quantified by counting the total number of writhes, which included abdominal muscle contractions and hind paw extension over 20 min (Koster, Anderson, \& De-Beer, 1959). The animals received PLS (30 $\mathrm{mg} \mathrm{kg}^{-1}$, i.p.) or sterile saline (control group, $0.9 \%, \mathrm{w} / \mathrm{v}$ ) $30 \mathrm{~min}$ before acetic acid injection. Morphine $\left(5 \mathrm{mg} \mathrm{kg}^{-1}\right.$, s.c.) was administered $30 \mathrm{~min}$ before acetic acid as a reference compound.

\subsection{Formalin test}

This test, which produces a local tissue injury to the paw, has been used as a model for tonic pain and localized inflammation pain (Hunskaar, Fasmer, \& Hole, 1985). Twenty microliters of $2.5 \%$ formalin was administered (i.p.) into the right hind paw of mice. The licking time was recorded from 0 to $5 \mathrm{~min}$ (phase 1 , neurogenic) and from 20 to $25 \mathrm{~min}$ (phase 2, inflammatory), after the formalin injection (Hunskaar \& Hole, 1987). The mice ( $n=5$ per group) were then treated with PLS ( $30 \mathrm{mg} \mathrm{kg}^{-1}$, i.p.) or sterile saline $(0.9 \%)$ $30 \mathrm{~min}$ before formalin injection. Morphine $\left(5 \mathrm{mg} \mathrm{kg}^{-1}\right.$, s.c.) was also administered $30 \mathrm{~min}$ before the formalin injection and used as a reference compound.

\subsection{Hot-plate test}

The hot plate test also measures analgesic activity (Eddy \& Leinback, 1953). Each mouse was placed twice onto a heated plate $\left(51 \pm 1^{\circ} \mathrm{C}\right)$ separated by a $30 \mathrm{~min}$ interval. The first trial familiarized the animal with the test procedure, and the second trial served as the control for the reaction time (licking the paw or jumping). Animals showing a reaction time greater than 20 s were excluded. After the second trial (control reaction time), groups of animals $(n=5)$ received sterile saline (0.9\%, i.p.), PLS ( $30 \mathrm{mg} \mathrm{kg}^{-1}$, i.p.), and morphine ( $5 \mathrm{mg} \mathrm{kg}^{-1}$, s.c.; reference drug). The reaction times were measured at time zero ( 0 time) and 30, 60, 90 and 120 min after the

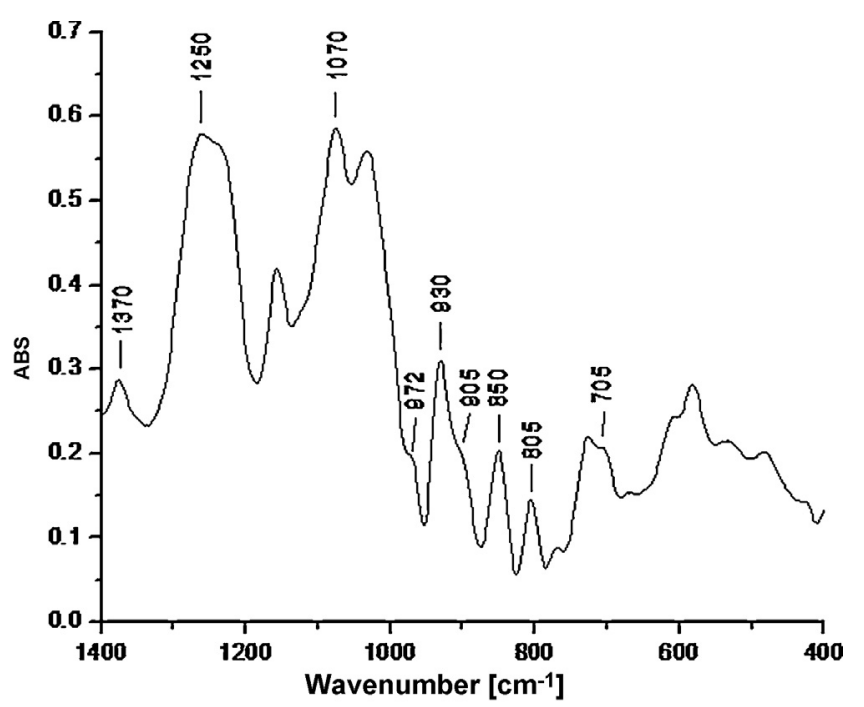

Fig. 1. FT-IR spectrum for KBr pellets of PLS fraction.

compounds were administered, with a cut-off time of $45 \mathrm{~s}$ to avoid paw lesions.

\subsection{Statistical analysis}

Results are expressed as mean \pm SEM from at least 5 animals per group. Statistical analysis was performed using ANOVA followed by Bonferroni post hoc test, when appropriate. Statistical significance was set at $P<0.05$.

\section{Results and discussion}

\subsection{Structural analysis of the sulfated galactan from A. ramosissima (PLS)}

Extraction from A. ramosissima yielded 45.2\% PLSs. The fraction extracted was rich in PLSs and had a soluble carbohydrate content of $64.4 \%$, moisture of $17.4 \%$ and ash of $18.1 \%$ with only traces of protein (content below 1\%). Sulphate content of soluble polysaccharide was $27.2 \%$. Although the use of enzymatic digestion and precipitation with cetyl pyridinium chloride (CPC) does not provide the maximum yield of gel in a single step, it provides a more purified fraction with a high content of PLSs and low protein content.

The monosaccharide composition (mol\%) of the PLS fraction showed galactose (44.8\%), 3,6-anhydrogalactose (23.8\%) and 6 -O-methylgalactose $(4.5 \%)$ and glucose $(26.9)$ as the main saccharides. The presence of glucose shows that same floridean starch was extracted in this procedure. Taking into account the percentage of glucose and total amount of carbohydrate we can estimate that the amount of galactose units (galactose $+3,6$ anhydrogalactose +6-0-methylgalactose) in relation to dry algae is around $21 \%$.

The FT-IR spectrum (Fig. 1) of soluble polysaccharide from A. ramosissima shows bands at $1259 \mathrm{~cm}^{-1}$ characteristic of the sulfate groups and at $930 \mathrm{~cm}^{-1}$ attributed to $\mathrm{C}-\mathrm{O}-\mathrm{C}$ of $3,6-$ anhydrogalactose. The region at $800-850 \mathrm{~cm}^{-1}$ is used for algal polysaccharides to characterize the sulfate pattern of agarocolloids. Two main bands at 850 and $805 \mathrm{~cm}^{-1}$ were assigned to sulfate substitution at C-4 of galactose and C-2 of anhydrogalactose (Bock, Pedersen, \& Pedersen, 1984; Furneaux, Miller, \& Stevenson, 1990). The shoulders at 972 and $905 \mathrm{~cm}^{-1}$ were attributed respectively to sulfate of $\alpha$-D-galactose and the presence of $\beta$-D-galactose without sulfate and/or its 6-O-methyl derivative 


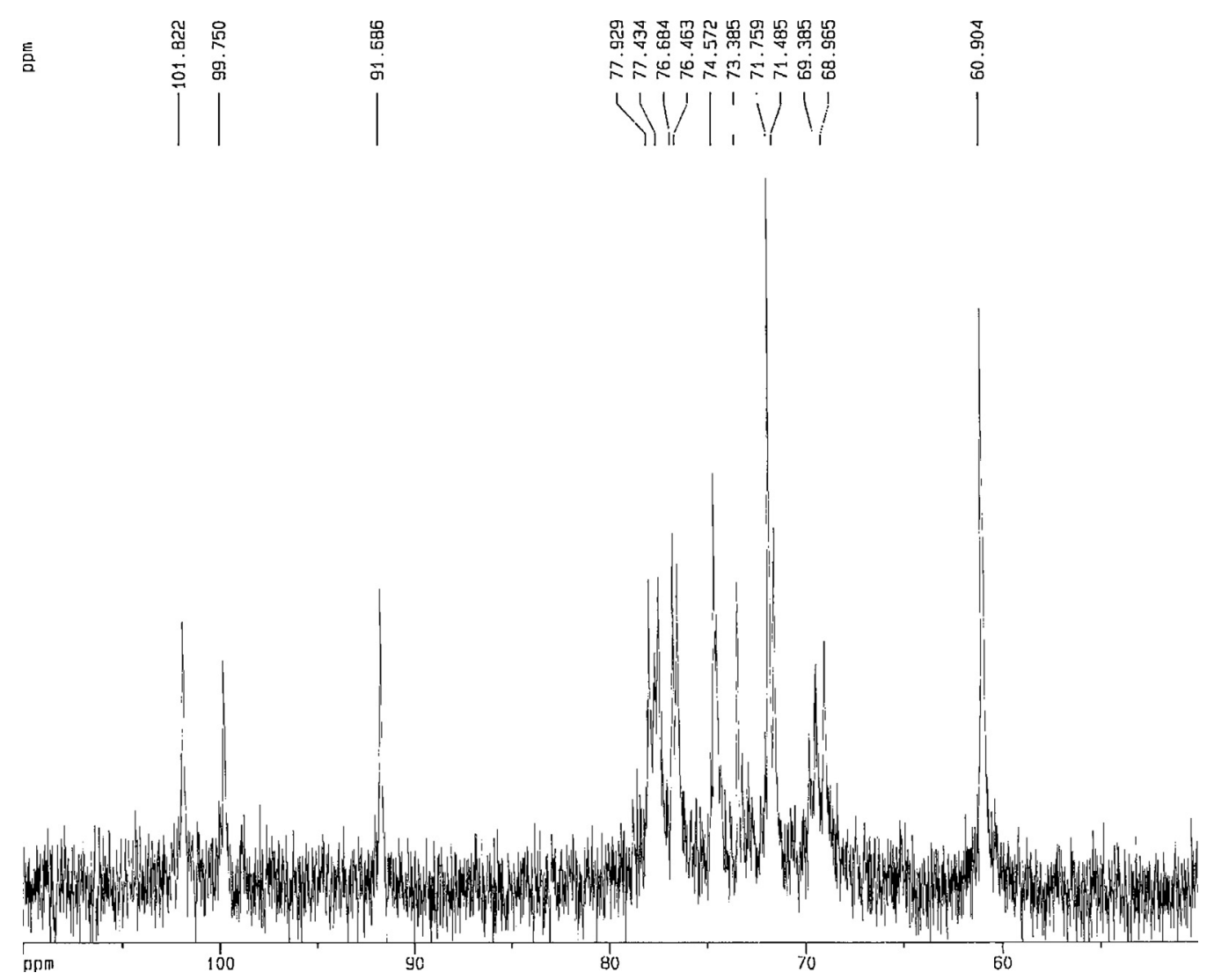

Fig. 2. ${ }^{13} \mathrm{C}$ NMR spectrum of the PLS fraction from Agardhiella ramossisima.

(Estevez, Ciancia, \& Cerezo, 2000). The presence of $\beta$-D-galactose without sulfate and/or its 6-O-methyl derivative observed by FRIR analyses corroborates with monosaccharide analysis where a high proportion of galactose was higher than of the 3,6anhydrogalactose.

The anomeric region of ${ }^{13} \mathrm{C}$ NMR (Fig. 2) shows three main signals, which were assigned based on literature data (Cases, Stortz, \& Cerezo, 1997; Falshaw, Furneaux, \& Miller, 1999; Lahaye, Yaphe, \& Rochas, 1985; Seymour, Knapp, \& Bishop, 1976) as C-1 of $\beta$-D-galactose-4 sulfate (G4S) at $\delta 101.8$ and $C-1$ of 3,6 anhydro- $\alpha$ D-galactose-2 sulfate (DA2S) at $\delta$ 91.7.This dyad is representative of a $\iota$ carrageenan structure. The other anomeric carbon is due glucose from floridean starch (899.7). Murano, Toffanin, Cecere, Rizzo, and Knutsen (1997) also detected floridean starch in polysaccharide extracted from Agardhiella subulata. Table 1 shows the attribution based on reference data of $\iota$ carrageenans fraction present in PLS. The ${ }^{13} \mathrm{C}$ NMR and FT-IR spectra indicates that the polysaccharide fraction extracted from $A$. ramosissima has a rich fraction of $\iota$ carrageenan, but PLS fraction also contains floridean starch.

\subsection{Biological activity of the sulfated galactan from A. ramosissima (PLS)}

\subsubsection{Effect of PLS on carrageenan type $\lambda$-induced paw oedema}

After being made to characterize the polymer (PLS) extracted from Agardhiella ramissisima we performed assays to evaluate the biological activity of this substance.

Polymers derived from algae, exhibit a wide range of pharmacological activities and are used worldwide in folk medicine (Agra, Silva, Basílio, França, \& Barbosa-Filho, 2008; Cabrita, Vale, \& Rauter, 2010; Vuorela et al., 2004; Zhang et al., 2010). In the present study, we investigated the possible anti-inflammatory properties of a PLS fraction extracted from the marine red algae $A$. ramosissima by using pharmacological tools and molecular procedures. Our results clearly demonstrate the anti-inflammatory and anti-nociceptive effects of PLS in models of inflammation (paw oedema and peritonitis) and nociceptive tests in mice.

Table 2 shows the paw volumes and percentages of inhibition of PLS and indomethacin in carrageenan-induced paw oedema. The results demonstred that carrageenan $(500 \mu \mathrm{g} / \mathrm{paw})$

Table 1

Chemical shift assignments for ${ }^{13} \mathrm{C}$ NMR spectra of PLS fraction from A. ramosissima (PLS).

\begin{tabular}{|c|c|c|c|c|c|c|}
\hline Carrageenan ${ }^{\mathrm{a}}$ & $\mathrm{C}-1$ & $C-2$ & $C-3$ & $C-4$ & $C-5$ & C-6 \\
\hline \multicolumn{7}{|l|}{ G4S } \\
\hline Observed & 101.8 & 68.9 & 76.4 & 71.8 & $74.4^{*}$ & 60.9 \\
\hline Reference $^{\mathrm{b}}$ & 102.2 & 69.3 & 76.8 & 72.2 & 74.8 & 61.3 \\
\hline \multicolumn{7}{|l|}{$D A 2 S$} \\
\hline Observed & 91.7 & 74.6 & 77.4 & 77.9 & 76.6 & 69.4 \\
\hline Reference $^{\mathrm{b}}$ & 92.1 & 75.0 & 77.8 & 78.3 & 77.0 & 69.8 \\
\hline
\end{tabular}

a G4S: $\beta$-D-galactose-4-sulfate; DA2S: 3,6-anhydro- $\alpha$-D-galactose-2-sulfate.

b Falshaw et al. (1996).

* This signal may be overlaped. 
increase in the volume of the right paw was measured at $3 \mathrm{~h}$ and $4 \mathrm{~h}$ after injection in the control mice. Indomethacin treatment at a dose of $10 \mathrm{mg} \mathrm{kg}^{-1}$ throughout the experimental period significantly inhibited hind paw swelling $\left({ }^{*} P<0.05\right)$, with maximal inhibition of $95.74 \%$ and maximal effect $3 \mathrm{~h}$ after injection. In the same table we observe that PLS (1, 10 and $30 \mathrm{mg} \mathrm{kg}^{-1}$ ) diminished carrageenan-induced paw oedema at all intervals. The maximal inhibitory effect occurred at a dose of $30 \mathrm{mg} \mathrm{kg}^{-1}$ ( $1 \mathrm{~h}: 0.020 \pm 0.008 \mathrm{~mL}^{*}, 73.33 \%$; $2 \mathrm{~h}: 0.013 \pm 0.005 \mathrm{~mL}^{*}$, 83.75\%; 3 h: $0.025 \pm 0.003 \mathrm{~mL}^{*}, 72.22 \%$; and $4 \mathrm{~h}: 0.013 \pm 0.004 \mathrm{~mL}^{*}$, $86.17 \%)$. Therefore, this dose was selected for studying the possible mechanisms of action involved in the PLS-mediated decrease of inflammation.

Carrageenan-induced acute paw inflammation has been characterized as a biphasic event, and a number of mediators are involved in this inflammatory reaction. Histamine, serotonin, bradykinin, and substance $P$ are released in the first phase. A delayed phase (after $2 \mathrm{~h}$ ) is primarily sustained by infiltration of granulocyte cells into the site of inflammation, inducing secretion of several proinflammatory mediators such as nitric oxide, prostaglandins, and cytokines (Di Rosa, Giroud, \& Willough, 1971; Gilligan, Lovato, Erion, \& Jeng, 1994).

The results of our experiment suggest that PLS exerts its antioedematogenic effects by inhibiting the two phases of carrageenaninduced oedema.

\subsubsection{Effect of PLS on dextran, histamine and serotonin-induced paw oedema}

This assays analyzed the ability of PLS to inhibit osmotic paw oedema. Our results demonstrated that dextran injection $(0.090 \pm 0.007 \mathrm{~mL}$; Fig. 3A), histamine $(0.090 \pm 0.008 \mathrm{~mL}$; Fig. 3B $)$ produced maximum peak oedema within $1 \mathrm{~h}$ after the administration and serotonin $(0.090 \pm 0.017 \mathrm{~mL}$; Fig. 3C) after $30 \mathrm{~min}$. Treatment of indomethacin inhibited paw oedema induced by dextran (Fig. 3A; $1 \mathrm{~h}: 0.011 \pm 0.006 \mathrm{~mL}$ ), histamine (Fig. 3B; $30 \mathrm{~min}$ : $0.006 \pm 0.003 \mathrm{~mL}$ ), and serotonin (Fig. $3 \mathrm{C} ; 1 \mathrm{~h}: 0.011 \pm 0.004 \mathrm{~mL}$ ). Pre-treatment with PLS ( $30 \mathrm{mg} \mathrm{kg}^{-1}$ ) effectively inhibited paw oedema induced by dextran (100\% inhibition; 30 min: Fig. $3 \mathrm{~A})$, histamine (95.55\%; 1 h: Fig. 3B), and serotonin (72.22\%; 1 h: Fig. 3C).

Dextran is a pro-inflammatory agent that promotes the release of vasoactive amines, such as histamine and serotonin, causing osmotic oedema characterized by an increase in vascular permeability and low levels of protein and neutrophils (Calixto, Campos, Otuki, \& Santos, 2004). Therefore, we can infer that PLS affects the vascular component of oedema, which appears to be mediated by the decreased action of histamine and serotonin.

\subsubsection{Effect of PLS on MPO concentration}

MPO activity is an indication of neutrophil infiltration in this study. We demonstrated that PLS $\left(30 \mathrm{mg} \mathrm{kg}^{-1}\right)$ inhibited the neutrophil-induced damage by reducing MPO activity in the paws of the mice (Chaves et al., 2013). Fig. 4 shows that PLS (30 $\mathrm{mg} \mathrm{kg}^{-1}$ ) inhibited neutrophil infiltration, which was evident from the MPO activity measured in the mice paws. The carrageenan sub-plantar group showed MPO activity at a concentration of $18.97 \pm 2.53 \mathrm{UMPO} / \mathrm{mg}$ of plantar tissue, while the group treated with PLS showed MPO activity of $2.76 \pm 1.17 \mathrm{UMPO} / \mathrm{mg}$ of plantar tissue, which is equivalent to a reduction of $85.45 \%$.

The inflammatory response induced by carrageenan in paw oedema also involves intense neutrophil infiltration (Carvalho et al., 1996; Hajare et al., 2001). Myeloperoxidase (MPO) is an enzyme found primarily in the azurophilic granules of neutrophils, and therefore, has been used extensively as a biochemical marker for granulocyte infiltration into various tissues (Bradley et al., 1982).
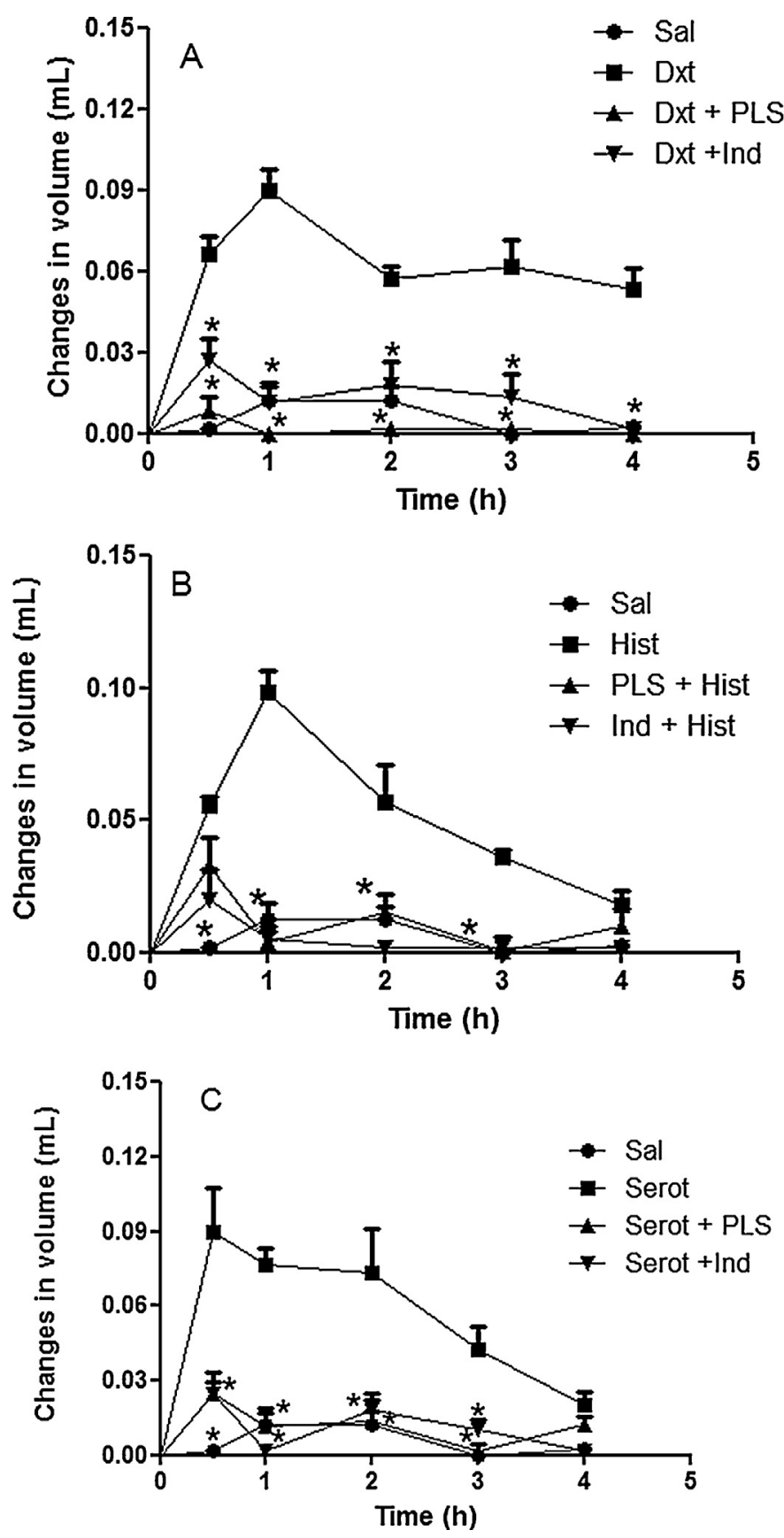

Fig. 3. Effect of PLS fraction on paw oedema induced by dextran, histamine and serotonin. Paw oedema was induced by dextran (Fig. 3A; $500 \mu \mathrm{g} /$ paw; $50 \mu \mathrm{L}$ ), histamine (Fig. 3B; 1\%,w/v; $50 \mu \mathrm{L}$ ), and serotonin (Fig. 3C; $1 \%, \mathrm{w} / \mathrm{v} ; 50 \mu \mathrm{L}$ ) injections into the plantar right paw. Paw volume was measured after $30 \mathrm{~min}, 1,2,3$, and $4 \mathrm{~h}$ for dextran, histamine, and serotonin injections. Animals were pretreated with PLS (30 $\mathrm{mg} \mathrm{kg}^{-1}$; i.p.), saline (Sal; control), or indomethacin (Ind; $10 \mathrm{mg} \mathrm{kg}^{-1}$; i.p.). Each point represents the mean \pm SEM of 5 animals. ${ }^{*} P<0.05$ indicates a significant difference from the dextran, histamine, or serotonin groups. Statistical analyses were performed using ANOVA followed by a Bonferroni post hoc test.

Thus, we can suggest that the anti-inflammatory action of PLS is dependent on the mechanisms of neutrophil migration.

\subsubsection{Effect of PLS on carrageenan-induced peritonitis in mice}

To reinforce the anti-inflammatory effect of PLS involved in diminishing neutrophil migration, we tested PLS in a carrageenaninduced peritonitis model. Fig. 5 shows the carrageenan increased the total leucocyte count of $8.22 \times 10^{6} \pm 0.57 \times 10^{3}$ cells $/ \mathrm{mL}$ (Fig. 5A) and neutrophil count of $4.63 \times 10^{3} \pm 0.35 \times 10^{3}$ cells $/ \mathrm{mL}$ 
Table 2

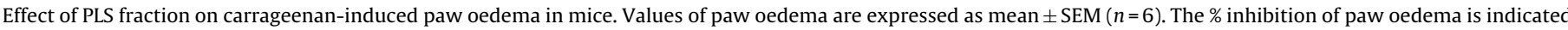
in parentheses. Carrageenan (Cg); PLS (sulphated polysaccharide fraction).

\begin{tabular}{|c|c|c|c|c|c|}
\hline \multirow[t]{2}{*}{ Treatment } & \multirow[t]{2}{*}{ Dose ( $\mathrm{mg} \mathrm{kg}^{-1}$ ) } & \multicolumn{4}{|l|}{ Paw oedema (mL) } \\
\hline & & $1 \mathrm{~h}$ & $2 \mathrm{~h}$ & $3 \mathrm{~h}$ & $4 \mathrm{~h}$ \\
\hline $\mathrm{Cg}$ & & $0.075 \pm 0.005$ & $0.080 \pm 0.005$ & $0.090 \pm 0.003$ & $0.094 \pm 0.009$ \\
\hline Saline & & $0.006 \pm 0.003$ & $0.001 \pm 0.001$ & $0.00 \pm 0.00$ & $0.001 \pm 0.001$ \\
\hline Indomethacin & 10 & $0.026 \pm 0.002^{*}(65.33)$ & $0.020 \pm 0.005^{*}(75.00)$ & $0.008 \pm 0.003^{*}(91.11)$ & $0.015 \pm 0.003^{*}(84.04)$ \\
\hline \multirow[t]{3}{*}{ PLS } & 1 & $0.036 \pm 0.009^{*}(52.00)$ & $0.048 \pm 0.013(59.92)$ & $0.045 \pm 0.010^{*}(49.91)$ & $0.063 \pm 0.017^{*}(57.62)$ \\
\hline & 10 & $0.033 \pm 0.004^{*}(56.00)$ & $0.025 \pm 0.006^{*}(68.75)$ & $0.025 \pm 0.007^{*}(72.22)$ & $0.021 \pm 0.007^{*}(77.65)$ \\
\hline & 30 & $0.020 \pm 0.008^{*}(73.33)$ & $0.013 \pm 0.005^{*}(83.75)$ & $0.025 \pm 0.003^{*}(72.22)$ & $0.013 \pm 0.004^{*}(86.17)$ \\
\hline
\end{tabular}

* Indicates $P<0.05$, as compared to Cg group. One-way ANOVA followed by a Bonferroni post hoc test.

(Fig. 5B). However, the administration of PLS (30 $\mathrm{mg} \mathrm{kg}^{-1}$, i.p.) 30 min before carrageenan injection significantly reduced this peritoneal leucocyte count to $4.31 \times 10^{6} \pm 0.71 \times 10^{3}$ cells $/ \mathrm{mL}$. The same dose of PLS also significantly reduced neutrophil migration into the peritoneal cavity to $1.90 \times 10^{3} \pm 0.49 \times 10^{3}$ cells $/ \mathrm{mL}$. Animals administered only indomethacin exhibited a reduced leucocyte count as shown in Fig. 5A and B.

Carrageenan induces neutrophil migration into the rats peritoneal cavity through an indirect mechanism that involves the activation of macrophages and the release of pro-inflammatory cytokines, such IL-1 $\beta$ and TNF- $\alpha$, into the peritoneal cavity (Lo, Almeida, \& Beaven, 1982). In this study, we showed for the first time that PLS also decreased leucocyte migration to the peritoneal cavity. According this data we can infer that the PLS decreased neutrophil migration by diminished the production and releasing of pro-inflammatory cytokines.

\subsubsection{Effect of PLS on nociceptive test}

3.2.5.1. Effect of PLS on acetic acid-induced writhing test. There is an association between the inflammatory process and the development of pain (Bitencourt et al., 2008). The anti-nociceptive effect of PLS extracted from A. ramosissima was evaluated using three

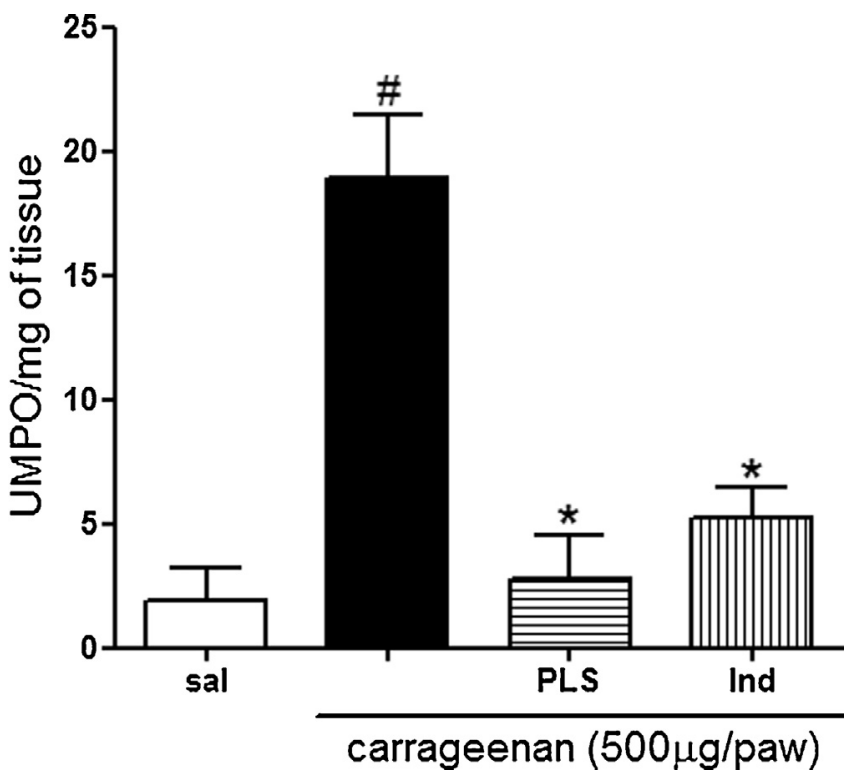

Fig. 4. Effect of PLS fraction on carrageenan-induced myeloperoxidase activity in paw tissue. Saline (Sal; s.c.) or carrageenan $(\mathrm{Cg} ; 500 \mu \mathrm{g} / \mathrm{paw})$ was injected into the plantar surface of mice. One hour before Sal or $\mathrm{Cg}$ injection, the animals were treated with indomethacin (IND; $10 \mathrm{mg} \mathrm{kg}^{-1}$, i.p.) or sulphated polysaccharide (PLS; $30 \mathrm{mg} \mathrm{kg}^{-1}$, i.p.) fraction. Myeloperoxidase (MPO) activity was detected in the paw tissue after $4 \mathrm{~h}$. The results are expressed as the mean \pm SEM MPO units (UMPO)/mg of tissue. * indicates $P<0.05$ compared to the $\mathrm{Cg}$ group; \# indicates $P<0.05$ between the Sal plus $C g$ group and the saline group. Statistical analyses were performed using an ANOVA followed by a Bonferroni post hoc test. well-accepted murine pain models, namely acetic acid-induced writhing, and formalin- and hot-plate-induced nociception tests. Our results demonstrated that PLS treatment (i.p.; $30 \mathrm{mg} \mathrm{kg}^{-1}$ ) in mice 30 min before acetic acid injection showed significant antinociceptive effect by inhibiting abdominal writhings (Fig. 6A). The percentage of inhibition was $82.0 \%$ in comparison to that in the control group (saline plus acetic acid). The inhibitory effect of the writhings was expressed more intensely when $5 \mathrm{mg} \mathrm{kg}^{-1}$ morphine (i.p.) was administered, indicating a decrease of $98.80 \%$. This
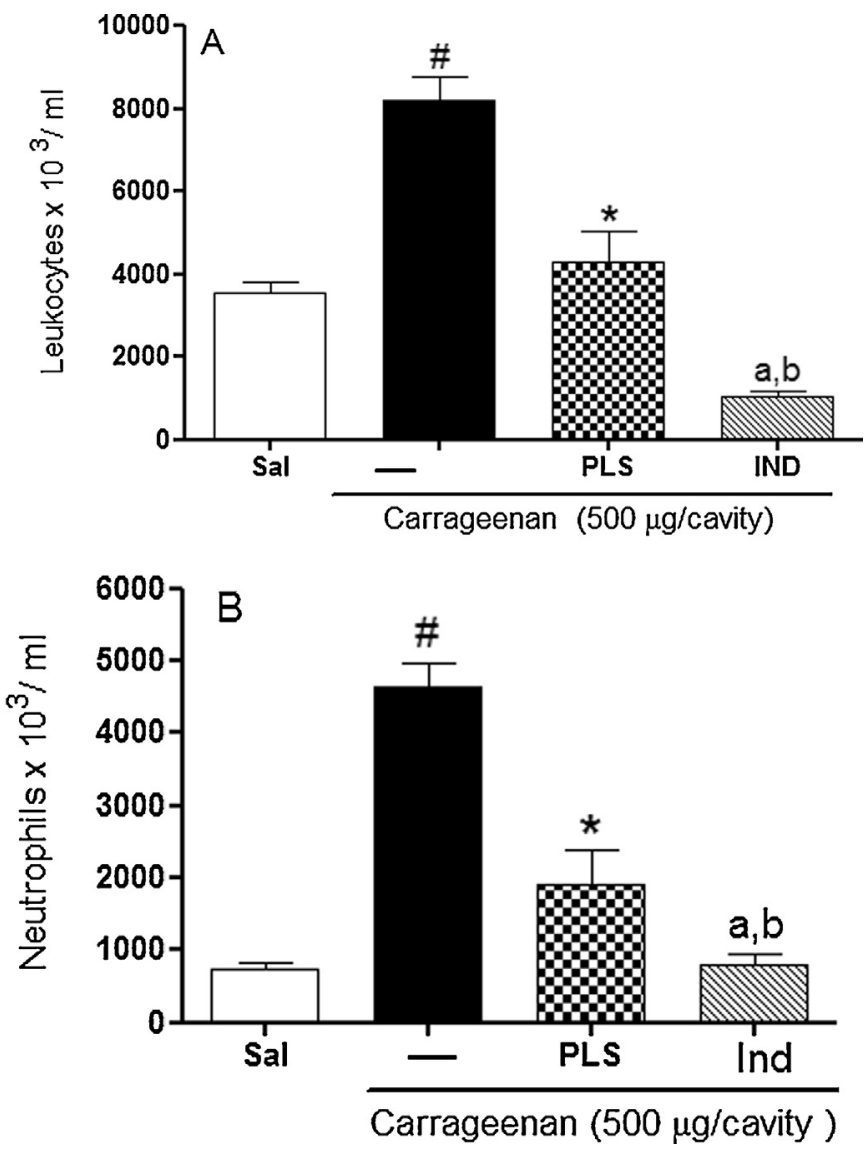

Fig. 5. Anti-inflammatory effect of PLS fraction on carrageenan-induced peritonitis in mice. (A) Total counts of leukocytes. (B) Counts of neutrophils per cavity. Mice were administered $250 \mu \mathrm{L}$ of saline (p.o.), indomethacin (Ind; $10 \mathrm{mg} \mathrm{kg}^{-1}$, p.o.), or sulphated polysaccharide (PLS; $30 \mathrm{mg} \mathrm{kg}^{-1}$, p.o.) fraction, followed by the injection of $500 \mu \mathrm{g}$ of carrageenan diluted in $250 \mu \mathrm{L}$ of saline solution (i.p.) after $1 \mathrm{~h}$. The mice were killed $4 \mathrm{~h}$ later, and the peritoneal cavity was washed with $1.5 \mathrm{~mL}$ of heparinised phosphate-buffered saline (PBS) to harvest the peritoneal cells. The white bars represent the peritoneal neutrophils in the saline-injected mice (control group). The values are represented as mean \pm SEM. \# indicates $P<0.05$ compared to the Sal group; * indicates $P<0.05$ compared to the carrageenan group; "a" indicates $P<0.05$ compared to the carrageenan group. "b" indicates $P<0.05$ compared to the PLS group. 

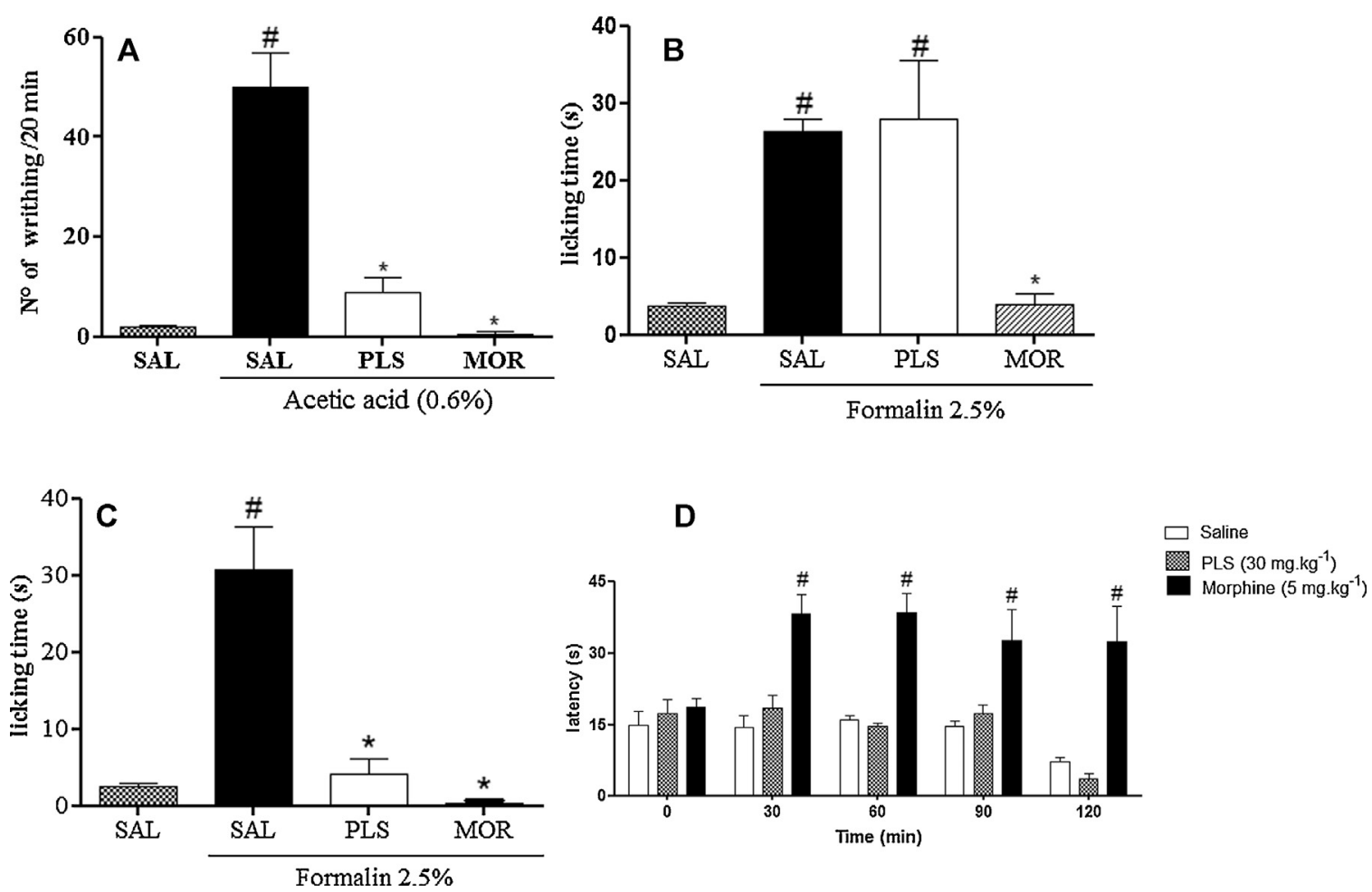

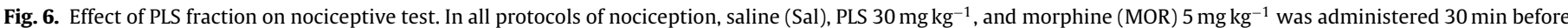

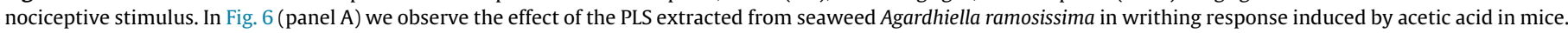

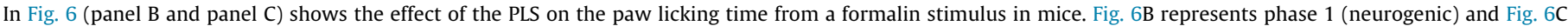

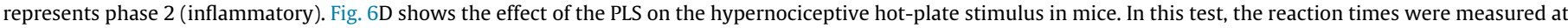

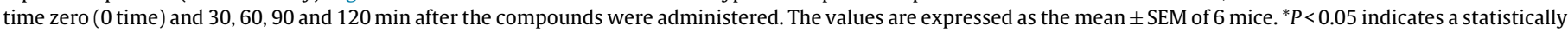

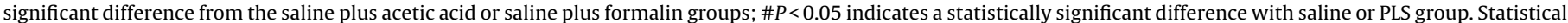
analyses were performed by an ANOVA followed by a Bonferroni post hoc test.

demonstrates the peripheral anti-nociceptive action of our PLS fraction.

The acetic acid-induced writhing reaction in mice has been largely used as a screening tool for the assessment of analgesic or anti-inflammatory properties of new agents, and has been described as a typical model for visceral inflammatory pain (Tjølsen \& Hole, 1997). The writhing test is commonly used for screening peripherally active analgesic. This model involves different nociceptive mechanisms, such as the release of biogenic amines (e.g., histamine and serotonin), cyclooxygenases and their metabolites (Duarte, Nakamura, \& Ferreira, 1988), and opioid mechanisms (Collier et al., 1968). These mediators activate chemosensitive nociceptors that contribute to the development of inflammatory pain (Corrêa et al., 1996; Ikeda, Ueno, Naraba, \& Oh-ishi, 2001; Ribeiro et al., 2000). PLS was able to reduce the writhings, suggesting that its anti-nociceptive effect could be related to the inhibition of the release of mediators in response to acetic acid.

3.2.5.2. Effect of PLS on formalin test. Formalin-induced nociception was another model utilized in this study. The acetic acid-induced abdominal writhing and hot plate test have been reported as being useful for investigation of peripheral or central activity, while the formalin-induced nociception test is valuable in detecting both effects (Tjølsen \& Hole, 1997). Our results demonstrated that the PLS ( $30 \mathrm{mg} \mathrm{kg}^{-1}$ ), injected i.p. $30 \mathrm{~min}$ before formalin, showed a significant anti-nociceptive effect, reducing the licking time, only in the second and inflammatory phase (Fig. 6C; 80.54\%) of the test in comparison to the control group (saline + formalin group). As expected, morphine significantly reduced the formalin response in both phases. The morphine inhibitory effect varied from an $85.25 \%$ reduction in licking time in the first phase (Fig. 6B) to a $98.05 \%$ reduction in the second phase (Fig. 6C).

Neurogenic and inflammatory pain was evaluated using the formalin test. The formalin response showed two phases. The first phase is characterized by neurogenic pain caused by a direct chemical stimulation of nociceptors. The second phase is characterized by inflammatory pain triggered by a combination of stimuli, including inflammation of the peripheral tissues and mechanisms of central sensitization (Tjølsen \& Hole, 1997; Tjølsen, Berge, Hunskaar, Rosland, \& Hole, 1992). In the latter phase, different chemical mediators are involved including excitatory amino acids, neuropeptides, PGE2, nitric oxide, and kinins (Malmberg \& Yaksh, 1995; Omote, Kawamata, Kawamata, \& Namiki, 1998; Santos \& Calixto, 1997; Tjølsen \& Hole, 1997; Vanegas \& Schaible, 2001).

Different mechanisms have been shown to be involved in first and second phase nociceptive behaviours, based on the differential pharmacology associated with these behaviours. It has been widely reported that both phases are sensitive to centrally acting drugs such as opioids (Shibata, Ohkubo, Takahasi, \& Inoki, 1989). However, the second phase is also sensitive to anti-inflammatory drugs. In our results, PLS inhibited only the second phase, suggesting that the anti-nociceptive effect of that polymer is related to inflammatory peripheral pain.

3.2.5.3. Effect of PLS on hot-plate test. To confirm that PLS diminishes inflammatory peripheral events, we performed the hot-plate test. The PLS did not show any anti-nociceptive effect in all intervals. The administration of the reference drug, morphine, at $5 \mathrm{mg} \mathrm{kg}^{-1}$ showed anti-nociception (Fig. 6D), with a delay in the reaction time of $35.95 \pm 4.16$ and $34.83 \pm 3.81 \mathrm{~s}$ compared to the 
saline group $(17.45 \pm 3.3$ and $15.95 \pm 1.00 \mathrm{~s})$ at 30 and $60 \mathrm{~min}$, respectively.

The test is a specific central anti-nociceptive test in which opioid agents exert their analgesic effects via the central nervous (Nemirovsky, Chen, Zelma, \& Jurna, 2001). PLS did not alter the increase in latency for jumping or licking in mice. These results suggest that PLS action depends on a peripheral, rather than a central-acting mechanism.

\section{Conclusion}

In conclusion, our work shows that the polymer extracted from A. ramossisima (PLS) has a rich fraction of carrageenan. It can be argued that PLS have anti-nociceptive and anti-inflammatory activities and may possibly act via inhibition of inflammatory mediators. However, pharmacological and chemical studies are needed in order to characterize the mechanism(s) responsible for the antinociceptive and anti-inflammatory actions and also to identify other active agents present in this alga. Moreover, the results obtained in this study contribute significantly to the pharmacological studies from marine compounds with anti-inflammatory and analgesic effects.

\section{Acknowledgments}

The authors gratefully acknowledge the technical assistance of Maria Silvandira Freire França, and we thank UFPI/CNPq for fellowship support.

\section{References}

Agra, M. F., Silva, K. N., Basílio, I. J. L. D., França, P. F., \& Barbosa-Filho, J. M. (2008). Survey of medicinal plants used in the region Northeast of Brazil. Brazilian Journal of Pharmacognsosy, 18, 472-508.

Arif, J. M., Al-Hazzani, A. A., Kunhi, M., \& Al-Khodairy, F. (2004). Marine compounds: Anticancer or genotoxic? Journal of Biomedicine and Biotechnology, 2, 93-98.

Barbosa-Filho, J. M., Alencar, A. A., Nunes, X. P., Tomaz, A. C. A., Sena-Filho, J. G., Athayde-Filho, P. F., et al. (2008). Sources of alpha-, beta-, gamma-, delta- and epsilon-carotenes: A twentieth century review. Brazilian Journal of Pharmacognsosy, 18, 135-154

Bitencourt, F. S., Figueiredo, J. G., Mota, M. R. L., Bezerra, C. C. R., Silvestre, P. P., Vale, M. R., et al. (2008). Antinociceptive and anti-inflammatory effects of a mucin-binding agglutinin isolated from the red marine alga Hypnea cervicornis. Naunyn-Schmiedeberg's Archives of Pharmacology, 377, 139-148.

Bock, K., Pedersen, C., \& Pedersen, H. (1984). Advances in Carbohydrate Chemistry and Biochemistry, 42, 193-225.

Bradford, M. M. (1976). A rapid and sensitive method for the quantitation of microgram quantities of protein utilizing the principle of protein-dye binding. Analytical Biochemistry, 72, 248-254.

Bradley, P. P., Christensen, R. D., \& Rothstein, G. (1982). Cellular and extracellular myeloperoxidase in pyogenic inflammation. Blood, 60, 618-622.

Cabrita, M. T., Vale, C., \& Rauter, A. P. (2010). Halogenated compounds from marine algae. Marine Drugs, 8, 2301-2317.

Calixto, J. B., Campos, M. M., Otuki, M. F., \& Santos, A. R. (2004). Anti-inflammatory compounds of plant origin. Part II. modulationof pro-inflammatory cytokines, chemokines and adhesion molecules. Planta Medica, 70, 93-103.

Carvalho, J. T. C., Teixeira, J. R. M., Souza, P. J. C., Bastos, J. K., Filho, D. S., \& Sarti, S. J. (1996). Preliminary studies of analgesic and anti-inflammatory properties of Caesalpinea ferrea crude extract. Journal of Ethnopharmacology, 53, 175-178.

Cases, M. R., Stortz, C. A., \& Cerezo, A. S. (1997). Carbohydrate. Polymers, 34, 61-65.

Chaves, L. S., Nicolau, L. A. D., Silva, R. O., Barros, F. C. N., Freitas, A. L. P., Aragão, K. S., et al. (2013). Anti-inflammatory and antinociceptive effects in mice of a sulfated polysaccharide fraction extracted from the marine red algae Gracilaria caudata. Immunopharmacology and Immunotoxicology, 35, 93-100.

Collier, H. D. J., Dinneen, L. C., Johnson, C. A., \& Schneider, C. (1968). The abdominal constriction response and its suppression by analgesic drugs in the mouse. British Journal of Pharmacology, 32, 295-310.

Corrêa, C. R., Kyke, D. J., Chakraverty, S., \& Calixto, J. B. (1996). Antinoci-ceptive profile of the pseudopepitide B2 bradykinin and receptor antagonist NPC 18688 in mice. British Journal of Pharmacology, 117, 552-558.

Corrêa, M. F. P., Melo, G. O., \& Costa, S. S. (2008). Natural products from plant origin potentially useful in the asthma therapy. Brazilian Journal of Pharmacognsosy, 18 , 785-797.

Cumashi, A., Ushakova, N. A., Preobrazhenskaya, M. E., D’Incecco, A., Piccoli, A., Totani, L., et al. (2007). A comparative study of the anti-inflammatory, anticoagulant, antiangiogenic, and antiadhesive activities of nine different fucoidans from brown seaweeds. Glycobiology, 17, 541-552.

Di Rosa, M., Giroud, J. P., \& Willough, D. A. (1971). Studies on the mediators of the acute inflammatory response induced in rats in different sites by carrageenan and turpentine. Journal of Pathology, 104, 15-29.

Dodgson, K. S., \& Price, R. G. (1962). A note on the determination of the ester sulphate content of sulphated polysaccharides. Biochemistry Journal, 84, $106-110$.

Duarte, I. D. G., Nakamura, M., \& Ferreira, S. H. (1988). Participation of the sympathetic system in acetic acid-induced writhing in mice. Brazilian Journal of Medical and Biological Research, 21, 341-343.

Dubois, M., Gilles, K. A., Hamilton, J. K., Rebers, P. A., \& Smith, F. (1956). Colorimetric method for determination of sugars and related substances. Analytical Chemistry, $28,350-356$.

Eddy, N. B., \& Leinback, D. (1953). Synthetic analgesics. II. Dithienyl-butenyl and dithienylbutylamines. Journal of Pharmacology and Experimental Therapeutics, 107, 385-393.

Estevez,J. M., Ciancia, M., \& Cerezo, A.S. (2000). The system of low-molecular-weight carrageenans and agaroids from the room-temperature-extracted fraction of Kappaphycus alvarezii. Carbohydrate Research, 325, 287-299.

Falshaw, R., Furneaux, R. H., \& Wong, H. (1996). Structural analysis of carrageenans from Burmese and Thai samples of Catenella nipae. Carbohydrate Research, 285 , 81-98.

Falshaw, R., Furneaux, R. H., \& Miller, I. J. (1999). Botanica Marina, 42, 431-435.

Furneaux, R. H., Miller, I. J., \& Stevenson, T. T. (1990). Hydrobiologia, 204, 645-654.

Gilligan, J. P., Lovato, S. J., Erion, M. D., \& Jeng, A. Y. (1994). Modulation of carrageenan-induced hind paw edema by substance P. Inflammation, 18, 285-292.

Hajare, S. W., Chandra, S., Charma, J., Tandan, S. K., Lal, J., \& Telang, A. G. (2001) Anti-inflammatory activity of Dalbergia sisso oleaves. Fitoterapia, 72, 131-139.

Hunskaar, S., \& Hole, K. (1987). The formalin test in mice: Dissociation between inflammatory and non-inflammatory pain. Pain, 30, 103-114.

Hunskaar, S., Fasmer, O. B., \& Hole, K. (1985). Formalin test in mice, a useful technique for evaluating mild analgesics. Journal of Neuroscience Methods, 14, 69-79.

Ikeda, Y., Ueno, A., Naraba, H., \& Oh-ishi, S. (2001). Involvement ofvanilloid receptor VR1 and prostanoids in the acid-induced writhing responses of mice. Life Science, 69, 2911-2919.

Kaji, T., Okabe, M., Shimada, S., Yamamoto, C., Fujiwara, Y., Lee, J. B., et al. (2004). Sodium spirulan as a potent inhibitor of arterial smooth muscle cell proliferation in vitro. Life Sciences, 26, 2431.

Konig, G. M., \& Wright, A. D. (1995). Marine natural products research: Current directions and future potential. Planta Medica, 62, 193-211.

Koster, R., Anderson, M., \& De-Beer, E. J. (1959). Acetic acid for analgesic screening. Federation Proceedings, 18, 412-418.

Kusaykin, M., Bakunina, I., Sova, V., Ermakova, S., Kuznetsova, T., Besednova, N., et al (2008). Structure, biological activity, and enzymatic transformation of fucoidans from the brown seaweeds. Biotechnology Journal, 3, 904-915.

Lahaye, M., Yaphe, W., \& Rochas, C. (1985). Carbohydrate Research, 143 $240-245$.

Lanhers, M. C., Fleurentin, J., Dorfman, P., Mortier, F., \& Pelt, J. M. (1991). Analgesic antipyretic and anti-inflammatory properties of Euphorbia hirta. Planta Medica, 57, 225-231.

Linley, J. E., Rose, K., Ooi, L., \& Gamper, N. (2010). Understanding inflammatory pain: Ion channels contributing to acute and chronic nociception. European Journal of Physiology, 459, 657-669.

Lo, T. N., Almeida, A. P., \& Beaven, M. A. (1982). Dextran and carra-geenan evoke different inflammatory responses in rat with respect to com-position of infiltrates and effect of indomethacin. Journal of Pharmacology and Experimental Therapeutics, 222, 261-267.

Malmberg, A. B., \& Yaksh, T. L. (1995). The effect of morphine on formalin-evoked behaviour and spinal release of excitatory amino acids and prostaglandin E2 using microdialysis in conscious rats. British Journal of Pharmacology, 114, 1069-1075.

Murano, E., Toffanin, R., Cecere, E., Rizzo, R., \& Knutsen, S. H. (1997). Investigation of the carrageenans extracted from Solieria filiformis and Agardhiella subulata from Mar Piccolo. Marine Chemistry, 58, 319-325.

Nemirovsky, A., Chen, L., Zelma, V., \& Jurna, I. (2001). The antinociceptive effect of the combination of spinal morphine with systemic morphine or buprenorphine. Anesthesiology. Analgesic, 93, 197-203.

Omote, K., Kawamata, T., Kawamata, M., \& Namiki, A. (1998). Formalin-induced release of excitatory amino acids in the skin of the rat hind paw. Brain Research, 787, 161-164.

Pereira, L., \& Mesquita, J. F. (2003). Carrageenophytes of occidental Portuguese coast: 1 -spectroscopic analysis in eight carrageenophytes from Buarcos bay Biomolecular. Engineering, 20, 217-222

Ribeiro, R. A., Vale, M. L., Thomazzi, S. M., Paschoalato, A. B., Poole, S., Ferreira, S. H., et al. (2000). Involvement of resident macrophages and mast cells in the writhing nociceptive responseinduced by zymosan and acetic acid in mice. European Journal of Pharmacology, 387, 111-118.

Rocha, A. C. C., Fernandes, E. S., Quintão, N. L. M., Campos, M. M., \& Calixto, J. B. (2006). Relevance of tumor necrosis factor- $\alpha$ for the inflammatory and nociceptive responses evoked by carrageenan in the mouse paw. British Journal of Pharmacology, 148, 688-695.

Santos, A. R. S., \& Calixto, J. B. (1997). Further evidence for the involvement of tachycinin receptor subtypes in formalin and capsaicin models of pain in mice. Neuropeptides, 31, 381-389. 
Selby, H. H., Whistler, R. L., \& Agar. (1993). R. L. Whistler, \& J. N. BeMiller (Eds.), Industrial gums: Polysaccharides and their derivatives (Vol. 3) (pp. 87-103). London: Academic Press.

Seymour, F. R., Knapp, R. D., \& Bishop, S. H. (1976). Carbohydrate Research, 51, $179-194$.

Shibata, M., Ohkubo, T., Takahasi, H., \& Inoki, R. (1989). Modified formalin test: Characteristic biphasic pain response. Pain, 38, 347-352.

Silva, R. O., Santos, G. M. P., Nicolau, L. A. D., Lucetti, L. T., Santana, A. P. M., Chaves, L. S. C., et al. (2011). Sulfated-polysaccharide fraction from red algae Gracilaria caudate protects mice gut against ethanol-induced damage. Marine Drugs, 9, $2188-2200$.

Sousa, F. C. F., Melo, C. T. V., Citó, M. C. O., Félix, F. H. C., Vasconcelos, S. M. M., Fonteles, M. M. F., et al. (2008). Medicinal plants and their bioactive constituents: A scientific review of bioactivity and potential benefits in the anxiety disorders in animal models. Brazilian Journal of Pharmacognsosy, 18, 642-654.

Srinivasan, K., Muruganandan, S., Lal, J., Chandra, S., Tandan, S. K., \& Prakash, V. R. (2001). Evaluation of anti-inflammatory activity of Pongamia pinnata leaves in rats. Journal of Ethnopharmacology, 78, 151-157.

Stevenson, T. T., \& Furneaux, R. H. (1991). Chemical methods for the analysis of sulphated galactans from red algae. Carbohydrate Research, 20, 277-298.

Therkelsen, G. H. Carrageenan. (1993). R. L. Whistler, \& J. N. BeMille (Eds.), Industrial gums: Polysaccharides and their derivatives (Vol. 3) (pp. 145-180). London: Academic Press.

Tjølsen, A., \& Hole, K. (1997). Animal models of analgesia. In A. Dickenson, \& J. Besson (Eds.), The pharmacology of pain (Vol. 130) (pp. 1-20). London: Springer Verlag.
Tjølsen, A., Berge, D. G., Hunskaar, S., Rosland, J. H., \& Hole, K. (1992). The formalin test: An evaluation of the method. Pain, 51, 5-17.

Usov, A. I. (2011). Polysaccharides of the red algae. Advances in Carbohydrate Chemistry and Biochemistry, 65, 115-217.

Vanegas, H., \& Schaible, H. G. (2001). Prostaglandins and ciclooxygenases in spinal cord. Progress in Neurobiology, 64, 327-363.

Vasconcelos, D. I. B., Leite, J. A., Carneiro, L. T., Piuvezam, M. R., Lima, M. R. V., Morais, L. C. R., et al. (2011). Anti-inflammatory and antinociceptive activity of ouabain in mice. Mediators of Inflammation, 11, 1-12.

Viegas, C., Jr., Bolzani, V. S., \& Barreiro, E. J. (2006). Os produtos naturais e a química medicinal moderna. Quimica Nova, 29, 326-337.

Vuorela, P., Leinonenb, M., Saikkuc, P., Tammelaa, P., Rauhad, J. P., Wennberge, T., et al. (2004). Natural products in the process of finding new drug candidates. Current Medicinal Chemistry, 11, 1375-1389.

Wijesekara, I., Pangestuti, R., \& Kim, S. K. (2011). Biological activities and potential health benefits of sulfated polysaccharides derived from marine algae. Carbohydrate Polymers, $84,14-21$.

Winter, C. A., Risley, E. A., \& Nuss, G. W. (1962). Carrageenin-induced edema in hind paw of the rat as an assay for antiiflammatory drugs. Proceedings of the Society for Experimental Biology and Medicine, 111, 544-547.

Zhang,J., Xia, W., Liu, P., Cheng, Q., Tahirou, T., Gu, W., et al.(2010). Chitosan modification and pharmaceutical/biomedical applications. Marine Drugs, 8, 1962-1987.

Zhou, G., Sun, Y., Xin, H., Zhang, Y., Li, Z., \& Xu, Z. (2004). In vivo antitumor and immunomodulation activities of different molecular weight lambdacarrageenans from Chondrusocellatus. Pharmacology Research, 50, 47-53. 